\title{
Provincially administered universal pharmacare programs require a secure, affordable drug supply: A matter of national security?
} The views expressed in this editorial are those of the author and do not necessarily reflect the position of the
Canadian Medical Association or its subsidiaries.

$\mathrm{n}$ the 1930s, the Ontario government won a lawsuit to force the withdrawal of a federal public service pamphlet which warned parents that thumb-sucking could lead to buckteeth in their children. This precedent and others like it are sufficient to prevent the federal government from providing health care, which is a provincial responsibility, in a system that allows regions to create their own priorities. ${ }^{1}$

The Hall Commission was cognizant of this restriction when it provided a pathway to publicly funded access to health care, which became a reality when the Medical Care Act of 1966 was added to the 1957 Hospital Insurance and Diagnostic Services Act. ${ }^{2}$ Less well known is the fact that the commission considered universal pharmacare an essential element of its plan. Justice Emmet Hall even considered specific ways to accommodate the pharmaceutical industry but prevent profiteering. ${ }^{3}$

Saskatchewan successfully operated a comprehensive universal pharmacare program for 12 years from 1975. Unlike other health care programs that were pioneered by Saskatchewan, pharmacare did not attract a funding partnership with the federal government. It was such funding partnerships that extended Saskatchewan's hospital insurance plan to the rest of Canada in 1957 and medicare in 1966. Indeed, during this period the federal government began its retreat from the original 50:50 cost-share agreement. For the Saskatchewan pharmacare program, the lack of federal funding came at a very bad time. When pharmacare was set up, it was rarely envisaged that patients would require either lifelong medications or take more than $1 \mathrm{drug}$ at a time. Most middle-aged Canadians today are taking at least 3 medications indefinitely to combat chronic illnesses such as hypertension, high cholesterol, diabetes, heartburn and arthritis. Many patients are taking a lot more than 3 drugs. Saskatchewan's universal pharmacare program lasted longer than expected. Today, provinces offer selective pharmacare programs such as the Ontario Drug Benefit program for low-income seniors and the extension of the Ontario Health Insurance Plan (OHIP+) for Ontario citizens under the age of 25 years.

The manufacture of drugs has been automated so that we have the highest production standards and the lowest cost in human history. Whereas profit margins on stan- dard drugs should have been reduced by this technology, pharmaceutical companies continue to be the most profitable of the manufacturing industries. They claim to have achieved this through innovation. Although some advances have been spectacular, many researchers believe the motivation behind most innovation is similar to the motivation to build a new-model-year car or design a new dress. Older, cheaper drugs have been abandoned for newer, more expensive alternatives whose incremental improvements are many times less than the increment in cost to the consumer. Haphazard production has resulted in critical shortages, euphemistically described as being "on backorder," that are a threat to health. At the other end of the spectrum, new therapies for previously untreatable conditions command astounding prices, often more than 10 times the annual salary of an average Canadian. Even private drug plans are having a hard time keeping up, such that many institutions are replacing drug-cost reimbursement plans with limited health spending accounts.

Provincially administered universal pharmacare requires access to medications. Providing a secure national drug formulary may well be a federal responsibility because it currently regulates the licensing of drugs. The provision of a Canadian drug formulary is sufficiently critical to our safety that it should be declared a matter of national security. This declaration would allow the federal government to use appropriate strategies to prevent profiteering, secure procurement and order manufacture as required for medications proven to be beneficial in common and rare conditions. A national formulary would not be a massive warehouse but a mixed-source supply strategy, available to provincial pharmacare plans, using many of the principles envisaged by Justice Hall.

In 1966, the health care insurance industry objected when their business appeared to have been taken by provincial insurance at a fraction of the administrative costs. Nonetheless, the private industry rebounded by providing coverage for add-on benefits. Likewise, there may be a place for private insurance to cover add-ons to pharmacare, such as the use of brand names over generic medications or coverage of treatments not provided by pharmacare. A national formulary would force 
experts to rationally debate the cost-effectiveness of medications rather than leave it, and all other aspects of drug availability, to the whims of the market. On June 20, 2018, Canada launched the Advisory Council on the Implementation of National Pharmacare. A national formulary could provide Dr. Eric Hoskins, chair of the advisory council, with the constitutional means to succeed, just as Justice Hall provided a pathway to medicare half a century ago.

Vivian C. McAlister, MB

Coeditor, Canadian fournal of Surgery
Competing interests: None declared. The views expressed are those of the author and do not necessarily reflect the views of employers or institutions with which the author is affiliated.

DOI: $10.1503 /$ cjs.010418

\section{References}

1. Harvey E. Trudeau government meddling in provincial mandates. Can F Surg 2017;60:4.

2. Government of Canada. Canada's Health Care System. www.canada. $\mathrm{ca} / \mathrm{en} / \mathrm{h}$ ealth-canada/services/health-care-system/reports-publications/ health-care-system/canada.html (accessed 23 June 2018).

3. Justice Emmett Hall. Farm Forum (interview), 2 Nov. 1964. CBC Digital Archives. www.cbc.ca/player/play/1801207811 (accessed 23 June 2018)

\section{Les régimes universels d'assurance médicaments provinciaux doivent pouvoir s'appuyer sur un approvisionnement sûr et abordable : Question de sécurité nationale?}

Les opinions exprimées dans cet éditorial sont celles de l'auteur et ne représentent pas nécessairement celles de I'Association médicale canadienne ou ses filiales.

ans les années 1930, le gouvernement ontarien a eu recours aux tribunaux pour forcer le retrait d'un dépliant du gouvernement fédéral qui mettait les parents en garde contre la surocclusion dentaire causée par la succion du pouce. Ce précédent et d'autres du même type sont suffisants pour empêcher le gouvernement fédéral de s'ingérer dans les soins de santé qui relèvent des compétences provinciales dans un système qui permet aux régions d'établir leurs propres priorités ${ }^{1}$.

La Commission Hall était au courant de cette restriction lorsqu'elle a ouvert la voie à un régime public de soins de santé, officialisé par l'adoption de la Loi sur les soins médicaux de 1966 qui s'ajoutait à la Loi sur l'assurance hospitalisation et les services diagnostiques de $1957^{2}$. Ce que l'on sait moins, c'est que la Commission plaçait l'assurance médicaments universelle au cœur de son régime. Le juge Emmet Hall avait même réfléchi à des façons spécifiques d'accommoder l'industrie pharmaceutique tout en mettant un frein à sa cupidité.

La Saskatchewan a géré avec succès un programme universel d'assurance médicaments complet pendant 12 ans à partir de 1975. Contrairement à d'autres régimes de soins de santé dont elle a été à l'avant-garde, le régime d'assurance médicaments de la Saskatchewan n'a pas suscité de financement en partenariat avec le gouvernement fédéral. C'est par ce type de financement en partenariat que le régime d'assurance hospitalisation de la Saskatchewan a essaimé vers le reste du Canada en 1957, suivi de l'assurance maladie en 1966. En effet, durant cette période, le gouvernement fédéral a commencé à se retirer de l'accord original de partage des coûts 50:50. Pour le programme d'assurance médicaments de la Saskatchewan, l'absence de financement fédéral est arrivée à un bien mauvais moment, car lors de sa mise sur pied, on imaginait mal que des patients puissent avoir besoin de médicaments tout au long de leur vie ou de plus d'un médicament à la fois. La plupart des Canadiens d'âge moyen aujourd'hui prennent au moins trois médicaments contre des maladies chroniques comme l'hypertension, l'hypercholestérolémie, le diabète, les brûlures d'estomac et l'arthrite. De nombreux patients prennent beaucoup plus que trois médicaments. Le programme universel d'assurance médicaments de la Saskatchewan a duré plus longtemps que prévu. De nos jours, les provinces offrent des programmes d'assurance médicaments sélectifs, par exemple, le programme d'assurance médicaments de l'Ontario pour les personnes âgées à faible revenu et l'extension du programme Assurance-santé Plus pour les citoyens ontariens de moins de 25 ans.

La fabrication des médicaments s'est automatisée. Nous disposons donc aujourd'hui de normes de production parmi les plus élevées au coût le plus faible de toute l'histoire de l'humanité. Tandis que les marges de profit 